\title{
A REVIEW OF ICT TECHNOLOGY IN CONSTRUCTION
}

\author{
Ehab J.Adwan ${ }^{1}$ and Ali Al-Soufi ${ }^{2}$ \\ ${ }^{1 \& 2}$ Department of Information Systems, University of Bahrain, Kingdom of Bahrain
}

\begin{abstract}
A growing awareness in the construction industry has emerged to pay a sharp attention to ICT as a catalyst that would mitigate the deficiencies characterized by this industry. In comparison with other cited review articles, this paper is aimed to 1) compile the research published on "ICT Technologies" in correspondence to "Construction Tasks" in the construction industry over the past two decades (19962016), 2) demonstrate the trends and patterns in the use of different types of ICT Technologies 3) discuss the correspondence of the identified ICT Technologies to the identified Construction Tasks and 4) exhibit the construction needs of ICT. By the employment of a five phases profiling methodology, a set of 68 out of 202 articles and papers indexed by Elsevier's Scopus database was considered relevant for the current review paper. This research is targeting the beginning researchers and practitioners in the field of ICT in construction.
\end{abstract}

\section{KEYWORDS}

Construction industry, Information, Technology, Ict, Construction Tasks, Article review.

\section{INTRODUCTION}

\subsection{RESEARCH GAP AND ORIGINALITY}

Despite the capabilities and effects of ICT, several scholarly review research endeavours have been proposed to investigate the ICT in construction industries. However, a rigorous review of ICT Technologies applied in the construction industry is missing. Most of those attempts were performed differently in terms of research intentions, objectives, purposes, types of ICT, duration of review, quality of review's methodological and analytical findings and review's implications. In this research paper, based on the applied profiling methodology, Elsevier Scopus database returned 9 indexed review articles. For example, [1] reviewed the advances in ICT in the UK virtual construction industry in terms of legal contractual issues basis to govern the electronic exchange of information. Similarly, [2] explored the use and prioritized needs of ICT in the Turkish construction industry in 2001 aiming to set an agenda for future developments and directions. Moreover, in Canada, [3] discussed the use, development and potential of ICT for the construction industry in terms of the implementation of sustainable design standards aiming to optimize the use of resources without negatively impacting the environment. However, [4] discussed the digital models; BIMs (Building Information Models) aiming to share rich semantic building information across different disciplines and related software applications. Similarly, [5] presented a future scenario-planning research aiming to find the future of construction industry being influenced by ICT changes in terms of the societal, economic, environmental and political 
factors. Very specifically, [6] reviewed the ICT applications in the field of earthquake bridge engineering, particularly the seismic design, construction and assessment of bridges. Similarly, [7] conducted a survey of digital technologies in procurement of construction projects (construction procurement Process). Finally, [8] focused on ICT that provides access to the data in managing issues within project management including, planning, risks, progress monitoring, quality control, etc. In comparison, this research paper provides a large coverage of technological ICT trends as will be discussed in the following subsection.

\subsection{RESEARCH AIM}

The aim of this article is to analyse the most cited research efforts published on ICT Technologies in the construction industry over the past two decades (1996-2016). This is achieved to understand the historical trends in the use of different types of ICT Technologies which will exhibit more potential research directions. This research has implications for the beginning researchers, practitioners and universities of the construction field and it forms the foundation for profiling other databases and specific types of construction related ICT journals and papers in this area.

\subsection{RESEARCH OBJECTIVES}

Since 1996, a number of quality academic outlets were dedicated to publish research on ICT and construction. Seeking for a quality and trustworthy database, Scopus is represented as one of the world's largest database of a trustworthy and peer-reviewed research which indexes most of those outlets (i.e. 20,500 titles and subject areas from thousands of publishers) all around the world. By employing a 5 phase's rigorous profiling methodology, this research intends to assess the availability of published research on ICT Technologies in correspondence to the available construction Tasks. From the empirical findings (using 4 mainstream keywords), initially 202 research works were identified from the Scopus database during the period 1996-2016. After assessing the 202 publications, 68 articles and papers were finally considered relevant and taken forward for further investigation. The rationale for undertaking this research is to provide a better understanding of the types of ICT Technologies employed along with the construction Tasks in the provided construction research, at which it will provide beginning researchers with the most widely employed construction related ICT technologies and tasks and of the editorial preferences of the journals and papers revealed as part of this research in terms of: 1) Review Sources, 2) Publications Frequency, 3) Citation analysis for each journal or paper, 4) Keyword Frequency and 5) Authors' Frequency. Therefore, the prime contribution of this research focuses on identifying the association of 1) Geo-spatial coverage, 2) Publication Types employed (i.e. Journal article or conference proceeding paper), 3) Research Methods employed (i.e. experiment, case study, mixed method, etc.), 4) Construction Tasks employed (i.e. Project management, HR Management, Cost, etc.), 5) ICT Technology employed (i.e. BIM based, Web based, information systems, etc.), 6) Association between the Construction Tasks and ICT Technologies and 7) ICT Technology and Construction Tasks Distribution. This comparison will provide insights into the historical trends and current patterns in using different types of ICT Technologies in the construction industry based on the determined construction Tasks. To achieve the abovementioned objectives, the authors contribute by conducting a review of 68 articles and papers. The remainder of this paper is structured as follows. Section 2 highlights the significance of ICT in construction and provides a definition to ICT. Thereafter, section 3 presents the research profiling methodology highlighting the overall research conducted in this paper. Then, in 
Section 4, we analyse and propose an overview of the research trends and patterns. Section 5 illustrates and discusses the analytical findings of the current paper. Finally, Section 6 concludes the paper by summarizing the empirical findings.

\section{CONSTRUCTION AND ICT}

\subsection{SIGNIFICANCE OF ICT}

[9] claims that an improvement in the information technology in construction (ITC) is a major international research endeavor in scientific institutions. [10] concurs with Amor's view that there is a growing body of knowledge from researchers and policy makers from the developed and the developing countries regarding the unequivocal importance and role of ICT as a prime tool that has the potential to modernize societies, boost economy, and bridge huge barriers such as distance, equity, and time associated with the traditional World.

\subsection{DEFINITION OF ICT}

Before getting into the details of ICT penetration in the construction industry, an agreed upon definition of ICT is a necessity. In this regard, [11] defined ICT as any product that stores, retrieves, manipulates, transmits or receives information electronically. [12] introduced the term ITC as a synonym to ICT, claiming that it has been used frequently worldwide. ITC was defined as the composite of information technology and construction and of the relationship between these two. Bjork further considered it as the domain of study of information technology in construction. Similarly, $[13,12]$ defined information technology as a collective reference to the integration of computing technology and information processing. They believed that ITC was not a single technology but a wide range of technical approaches to a variety of problems. Therefore, ITC was defined as the application of decision support tools which uses electronic machines and programs for processing, storage, analysis, control, transfer and presentation of construction information data during the whole life cycle of a construction project. Alternatively, [14] defined ICT as a combination of communication systems and technical decision support systems. Respectively, the first refers to any independent device capable of providing communication like telephones, faxes, laptops while the second refer to computer applications. However, [15] defined ICT as a combination of automation, and information and communications technology. Automation is the use of computers to replace and/or enhance a variety of jobsite applications which includes surveying, the control of equipment, and the installation of prefabricated units using Global Positioning System (GPS) technologies and advanced robotic systems. However, Construction ICT entailed the use of computer systems that are capable of capturing, organizing, storing, analyzing, exchanging, transmitting, and sharing information namely, video conferencing, web based project management, DBMS, data warehousing, and data mining.

\section{RESEARCH METHODOLOGY}

Searching for ICT Technology and construction Tasks in the construction field based on Elsevier's Scopus database revealed an interrelated and large amount of work. Consequently, this study aims to develop a comprehensive review of the subject following five phases of research profiling methodology. 


\section{PhaSe 1- SElection Of Data SourCes}

Several Constructions Related ICT Articles And Papers Were Determined Based On The Following Four Steps. 1) We Restricted The Selection Based On The Publication Year. To Limit The Searching Into Two Decades, Publication Year Was Specified To The Period Between 19962016. 2) Source Type (i.e. Journal or Conference proceeding, etc.) was set to be all. 3) Document type (i.e. Article or Paper, etc.) was set to all as well. 4) We then entered several keywords (including Plurals and synonyms) related to the research as demonstrated in Table 1. When calculated based on journals, conference proceedings and others respectively, the average ICT keywords scored higher percentage rates in the conference proceedings $(\mathrm{CP})$ and other source types while construction keywords scored higher in the journal (J) source types. The overall Total percentage demonstrates the presidency of the construction keywords with a 52\% compared to the ICT with $48 \%$.

\section{PHASE 2- APPLYING SEARCHING FORMUla}

We employed a formula: (KEY(information technology)AND KEY ("information and communication technologies") AND KEY ("construction") AND TITLE-ABS-KEY ("information and communication technology")) AND PUBYEAR > 1995 AND PUBYEAR < 2017 AND (LIMIT- TO (LANGUAGE, "English")) ). The period was limited to two decades (1996-2016) and the language was limited to English. Document type was introduced to demonstrate the fine details corresponding to each source type. Table 2 demonstrates the findings at which a total of 197 research work was revealed for each source type and each subset of document type.

\section{Phase 3- Refining The Document Type Items}

To maintain the originality and novelty of the current research work, Table 3 demonstrates the exclusion of the review articles $(\mathrm{F}=9)$ and other document $(\mathrm{F}=1)$ from the analysis efforts, though they were read and analysed to determine the research gap as mentioned in section 1.1. The exclusion effort returned 172 research works.

Table 1. Review's Sources per keyword

\begin{tabular}{lccccc}
\hline & \multicolumn{5}{c}{ Source Type } \\
\hline KEYWORDS & $\mathrm{J}$ & $\mathrm{CP}$ & Others & $\mathrm{F}$ & $(\mathrm{F} \%)$ \\
\hline "construction" & 144,927 & 68,630 & 42,690 & 256.247 \\
$\begin{array}{l}\text { information technology } \\
\text { "information and communication }\end{array}$ & 63,774 & 96,335 & 38,952 & 199.061 & 12.225 \\
technologies" & 5,768 & 5,327 & 1,130 & & \\
"information and communication & 13,895 & 7,223 & 4,017 & 25.135 & \\
technology" & 144.927 & 68,630 & 42,690 & 256.247 & $52.02 \%$ \\
\hline Total "Construction” Frequency & 83.437 & 108.885 & 44.099 & 236.421 & $47.98 \%$ \\
\hline Total "ICT" Frequency & 228.364 & 177.515 & 86.789 & 492.668 & \\
\hline Total "Construction” +“ICT” Frequency & $63.47 \%$ & $38.67 \%$ & $49.18 \%$ & $50.44 \%$ & \\
\hline Construction Percentage (\%) & $36.53 \%$ & $61.33 \%$ & $50.81 \%$ & $49.55 \%$ & \\
\hline ICT Percentage (\%) & & & & & \\
\hline
\end{tabular}


International Journal of Managing Information Technology (IJMIT) Vol.8, No.3/4, November 2016

Table 2. Findings of the searching formula

\begin{tabular}{|c|c|c|c|c|c|c|c|c|c|c|c|c|c|}
\hline \multicolumn{14}{|c|}{ Source Type } \\
\hline \multicolumn{5}{|c|}{ Journal } & \multicolumn{3}{|c|}{ Conference } & \multicolumn{5}{|c|}{ Other } & Total \\
\hline \multicolumn{5}{|c|}{ Document Type } & \multicolumn{3}{|c|}{ Document Type } & \multicolumn{5}{|c|}{ Document Type } & \\
\hline $\begin{array}{l}\text { Arti } \\
\text { cle }\end{array}$ & $\begin{array}{c}\text { Pape } \\
\text { r }\end{array}$ & $\begin{array}{c}\text { Revie } \\
\text { w }\end{array}$ & $\begin{array}{l}\text { Oth } \\
\text { er }\end{array}$ & Tot & $\begin{array}{l}\text { Articl } \\
\mathrm{e}\end{array}$ & Paper & Tot & $\begin{array}{l}\text { Arti } \\
\text { cle }\end{array}$ & $\begin{array}{l}\text { Pape } \\
\mathrm{r}\end{array}$ & $\begin{array}{l}\text { Cha } \\
\text { pter }\end{array}$ & $\begin{array}{l}\mathrm{Su} \\
\mathrm{rv}\end{array}$ & $\begin{array}{l}\text { To } \\
t\end{array}$ & 197 \\
\hline 84 & 9 & 5 & 1 & 99 & 2 & 81 & 83 & 2 & 9 & 2 & 2 & 15 & \\
\hline
\end{tabular}

Table 3. Refining the Document type items

\begin{tabular}{lccccc}
\hline \multicolumn{1}{c}{ Source Type } & \multicolumn{5}{c}{ Document Type } \\
\hline Journal and Conference & Articl & Paper & Revie & Other & Total \\
\cline { 2 - 7 } Proceedings & 86 & 86 & 9 & 1 & 182 \\
\hline & 86 & 86 & 0 & 0 & 172 \\
\hline
\end{tabular}

\section{PHASE 4- MANUAL REVIEWING AND EXCLUSION}

The manual reviewing of the 172 revealed the irrelevance and inadequacy of 38 research works despite their inclusion of the previously employed keywords. For example, the word construction in conjunction with ICT was used in some articles to mean designing and implementing ICT products.

\section{PHASE 5- SELECT THE MOST CiTED WORK}

Elsevier's Scopus provides a citation index for all of its sources. Sorting the records based on (C $>=1$ ) value returned an overall of 68 articles and papers. Consecutively, Table 4 and Table 5 demonstrate the frequency and citation rates of journal articles and conference proceedings papers. It was found that journal articles w.r.t. conference papers represent $(\mathrm{F}=68, \mathrm{~F} \%=51.5 \%)$ and with a total citation rate of $(\mathrm{TC}=745, \mathrm{TC} \%=(98.1 \%)$. However, conference papers w.r.t. journal articles represented $(\mathrm{F}=60, \mathrm{~F} \%=45.45 \%)$ and $(\mathrm{TC}=14, \mathrm{TC} \%=1.84 \%)$.

Table 4. Frequency and citation rates of Journal articles

\begin{tabular}{|c|c|c|c|c|c|}
\hline JOURNAL ARTICLES & $\mathrm{F} \%$ & $\mathrm{C} \%$ & JOURNAL ARTICLES & $\mathrm{F} \%$ & $\mathrm{C} \%$ \\
\hline Automation in Construction & 14.7 & 42 & Environmental Monitoring and Assessment & 1.5 & 0.81 \\
\hline Electronic Journal of Information Technology in & 14.7 & 12.8 & Hydrology and Earth System Sciences & 1.5 & 0.81 \\
\hline Construction Management and Economics & 10.3 & 17.6 & International Journal of Information Management & 1.5 & 0 \\
\hline Journal of Construction Engineering and & 7.4 & 4.7 & Journal of Urban Technology & 1.5 & 0.81 \\
\hline Journal of Management in Engineering & 5.9 & 2.82 & Marine Technology Society Journal & 1.5 & 2.28 \\
\hline Engineering, Construction and Architectural & 4.4 & 6.31 & Open Electrical and Electronic Engineering Journal & 1.5 & 0 \\
\hline International Journal of Project Management & 2.9 & 2.01 & Personal and Ubiquitous Computing & 1.5 & 0.4 \\
\hline Journal of Computing in Civil Engineering & 2.9 & 1.21 & Practice Periodical on Structural Design and & 1.5 & 0 \\
\hline Journal of Engineering, Design and Technology & 2.9 & 0.13 & Remote Sensing & 1.5 & 0.13 \\
\hline Journal of Professional Issues in Engineering & 2.9 & 0 & Social and Cultural Geography & 1.5 & 0.13 \\
\hline New Technology, Work and Employment & 2.9 & 0.81 & Structural Engineer & 1.5 & 0.27 \\
\hline Architectural Engineering and Design Management & 1.5 & 0.27 & Systemic Practice and Action Research & 1.5 & 0.67 \\
\hline Building Engineer & 1.5 & 0 & Tunnelling and Underground Space Technology & 1.5 & 1.21 \\
\hline Canadian Journal of Civil Engineering & 1.5 & 1.48 & Urban Forum & 1.5 & 1.48 \\
\hline Electronic Journal of Geotechnical Engineering & 1.5 & 0 & World Transactions on Eng and Tech Education & 1.5 & 0.13 \\
\hline $\begin{array}{l}\text { Frequency of Journal Articles w.r.t. Conference } \\
\text { Papers }\end{array}$ & & & $68 / 132$ & & \\
\hline $\mathrm{F}(\%)$ & & & $51.5 \%$ & & \\
\hline Total Citation w.r.t. Conference Papers & & & $745 / 759$ & & \\
\hline $\mathrm{TC}(\%)$ & & & $98.1 \%$ & & \\
\hline
\end{tabular}


International Journal of Managing Information Technology (IJMIT) Vol.8, No.3/4, November 2016

Table 5. Frequency and citation rates of Conference proceedings papers

\begin{tabular}{|c|c|c|c|c|c|}
\hline CONFERENCE PROCEEDINGS & $\mathrm{F} \%$ & $\begin{array}{l}\mathrm{C} \\
\%\end{array}$ & CONFERENCE PROCEEDINGS & $\begin{array}{l}\mathrm{F} \\
\%\end{array}$ & $\begin{array}{l}\mathrm{C} \\
\% \\
\end{array}$ \\
\hline $\begin{array}{l}\text { Association of Researchers in Construction Management, } \\
\text { ARCOM } 2005 \text { - Proceedings of the } 21 \text { st Annual Conference }\end{array}$ & 13 & 21 & $\begin{array}{l}\text { CRIOCM } 2010 \text { - International Symposium on } \\
\text { Advancement of Construction Management and Real }\end{array}$ & 2 & 0 \\
\hline COBRA 2008 - Construction and Building Research & 8 & 0 & $\begin{array}{l}\text { Fstate "Tnwarts Sustainahle Develonment of } \\
\text { IEEE International Conference on Industrial Informatics }\end{array}$ & 2 & 0 \\
\hline 2007 International Conference on Convergence Information & 3 & 0 & IMSCI 2007 - International Multi-Conference on & 2 & 0 \\
\hline Building a Sustainable Future - Proceedings of the 2009 & 3 & 7 & International Conference on Information Systems 2011, & 2 & 0 \\
\hline Civil-Comp Proceedings & 3 & 0 & International Multidisciplinary Scientific & 2 & 0 \\
\hline Construction Research Congress & 3 & 0 & ISEC 2015 - 8th International Structural Engineering & 2 & 0 \\
\hline ICCREM 2013: Construction and Operation in the Context & 3 & 0 & ISRM International Symposium - 8th Asian Rock & 2 & 0 \\
\hline ISARC 2008 - Proceedings from the 25 th International & 3 & 21 & PICMET '10 - Portland International Center for & 2 & 0 \\
\hline Proceedings, Annual Conference - Canadian Society for & 3 & 0 & Proceedings of IGLC17: 17th Annual Conference of the & 2 & 0 \\
\hline WIT Transactions on Ecology and the Environment & 3 & 0 & Proceedings of the 28th International Symposium on & 2 & 0 \\
\hline 13th International Group for Lean Construction Conference: & 2 & 36 & Proceedings of the 6th European Conference on Product & 2 & 0 \\
\hline 2008 3rd International Conference on Information and & 2 & 0 & Proceedings of the 8th International Conference on & 2 & 0 \\
\hline 2012 International Symposium on Management of & 2 & 0 & Proceedings of the European and Mediterranean & 2 & 0 \\
\hline 2012 Proceedings of Portland International Center for & 2 & 0 & Queensland University of Technology Research Week & 2 & 0 \\
\hline 21st Annual Conference of the International Group for Lean & 2 & 0 & Recent Researches in Communications and IT - Proc. of & 2 & 0 \\
\hline 9th European Conference on eLearning 2010, ECEL 2010 & 2 & 0 & Safety, Reliability and Risk Analysis: Theory, Methods & 2 & 0 \\
\hline ASEE Annual Conference and Exposition, Conference & 2 & 0 & Structures Congress 2014 - Proceedings of the 2014 & 2 & 7 \\
\hline CESB 2007 PRAGUE International Conference - Central & 2 & 0 & Summer Computer Simulation Conference 2007, & 2 & 0 \\
\hline CME 2007 Conference - Construction Management and & 2 & 0 & Synthetic Landscapes - ACADIA 2006 International & 2 & 7 \\
\hline \multirow[t]{2}{*}{ Congress on Computing in Civil Engineering, Proceedings } & 2 & 0 & TAC/ATC 2004 - 2004 Annual Conference and & 2 & 0 \\
\hline & 2 & 0 & World Conference on Timber Engineering 2012, WCTE & 2 & 0 \\
\hline Frequency of Conference Papers w.r.t. Journal Articles & & & $\begin{array}{c}60 / 132 \\
\%\end{array}$ & & \\
\hline $\mathrm{F}(\%)$ & & & $45.45 \%$ & & \\
\hline TOTAL Citation w.r.t. Journal Articles & & & $14 / 759$ & & \\
\hline $\mathrm{TC}(\%)$ & & & $1.84 \%$ & & \\
\hline
\end{tabular}

\section{RESEARCH TRENDS}

\subsection{REVIEW SOURCES}

As per Table 4, and Table 5, selecting the most frequent Journal articles of higher total citation rate revealed the presidency of Automation in Construction and Electronic Journal of Information Technology in Construction with $(\mathrm{F}=14.7 \%, \mathrm{C}=42 \%$ and $12.8 \%)$ respectively. This is followed by Construction Management and Economics $(\mathrm{F}=10.3 \%, \mathrm{C}=17.6 \%)$, then by Journal of Construction Engineering and Management $(\mathrm{F}=7.4 \%, \mathrm{C}=4.7 \%)$, then by Journal of Management in Engineering $(\mathrm{F}=5.9 \%, \mathrm{C}=2.8 \%)$ and Engineering, Construction and Architectural Management $(\mathrm{F}=4.4 \%, \mathrm{C}=6.3 \%)$. International Journal of Project Management, Journal of Computing in Civil Engineering, Journal of Engineering, Design and Technology, Journal of Professional Issues in Engineering Education and Practice and New Technology, Work and Employment scored $(\mathrm{F}=2.9 \%$ and $\mathrm{C}=0 \%-2.01 \%)$. The remaining journals scored $(\mathrm{F}=1.5 \%$ and $\mathrm{C}=0 \%-1.48 \%$ ). Moreover, selecting the most frequent conference proceeding papers of higher total citation rate revealed the presidency of Association of Researchers in Construction ( $\mathrm{F}=18 \%$, $\mathrm{C}=21 \%)$, COBRA 2008 - Construction and Building Research ( $\mathrm{F}=8 \%, \mathrm{C}=0 \%), 2007$ International Conference on Convergence $(\mathrm{F}=3 \%, \mathrm{C}=0 \%)$, Building a Sustainable Future - Proceedings of the 2009( $\mathrm{F}=3 \%, \mathrm{C}=7 \%)$, Civil-Comp Proceedings ( $\mathrm{F}=3 \%, \mathrm{C}=0 \%)$, Construction Research Congress $(\mathrm{F}=3 \%, \mathrm{C}=0 \%)$, ICCREM $2013(\mathrm{~F}=3 \%, \mathrm{C}=0 \%)$, ISARC 2008( $\mathrm{F}=3 \%, \mathrm{C}=21 \%)$, Proceedings, Annual Conference - Canadian Society for Civil Engineering $(\mathrm{F}=3 \%, \mathrm{C}=0 \%)$ and WIT Transactions on Ecology and the Environment $(\mathrm{F}=3 \%, \mathrm{C}=0 \%)$. Remaining conference proceedings scored $(\mathrm{F}=2 \%$ and $\mathrm{C}=0 \%-36 \%)$. 
International Journal of Managing Information Technology (IJMIT) Vol.8, No.3/4, November 2016

\subsection{Publication Frequency}

Figure 1 depicts the frequency of publications of the resulting articles and papers for the period $(1996-2016)$ with an average of $(\mathrm{F}=12, \mathrm{~F} \%=9 \%)$. Year 2010 has the highest publication rate with $(\mathrm{F}=26, \mathrm{~F} \%=19.5 \%)$, followed by year 2009 with $(\mathrm{F}=16, \mathrm{~F} \%=12 \%)$ and by year 2011 with $(\mathrm{F}=12, \mathrm{~F} \%=9 \%)$ respectively. All other remaining years scored below the average with $(\mathrm{F} \%=$ $8.3 \%)$ for years 2007 and 2014, $(\mathrm{F} \%=7 \%)$ for years 2012 and 2013. The least slice goes for years 1996, 1998, 1999 and 2001 which scored $(\mathrm{F} \%=0 \%)$ publications.

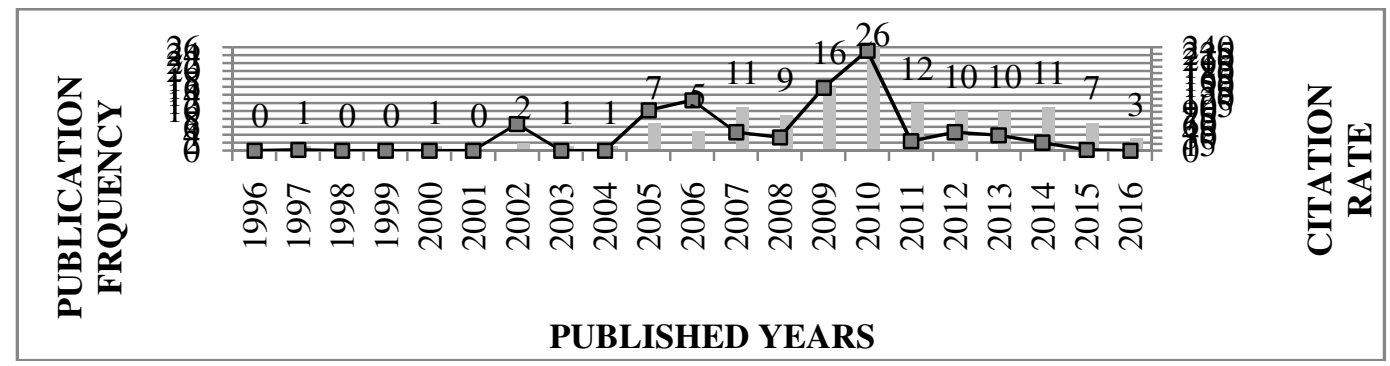

Figure 1. Publication frequency during (1996-2016)

\subsection{Citation Analysis}

Figure 2 depicts in grey shaded slope the total citation analysis of the resulting articles and papers for the period (1996-2016). Year 2010 has the highest citation rate of $(\mathrm{C}=232, \mathrm{C} \%=27.4 \%)$, followed by year 2009 of $(\mathrm{C}=146, \mathrm{C} \%=17.3 \%)$ and by year 2006 of $(\mathrm{C}=117, \mathrm{C} \%=13.8 \%)$, then followed by year 2005 of $(\mathrm{C}=94, \mathrm{C} \%=11.1 \%)$, year 2002 of $(\mathrm{C}=62, \mathrm{C} \%=7.3 \%)$, year 2007 and year 2012 of $(\mathrm{C}=42, \mathrm{C} \%=5 \%)$. The remaining years are all below the average with $(\mathrm{C} \%=4.3 \%)$ for years 2013, $(\mathrm{C} \%=3.7 \%)$ for year 2008 and $(\mathrm{C} \%=2.6 \%)$ for years 2011 and 2014. The least slice goes for years 1996, 1998, 1999 and 2001 with $(\mathrm{C} \%=0 \%)$ publications.

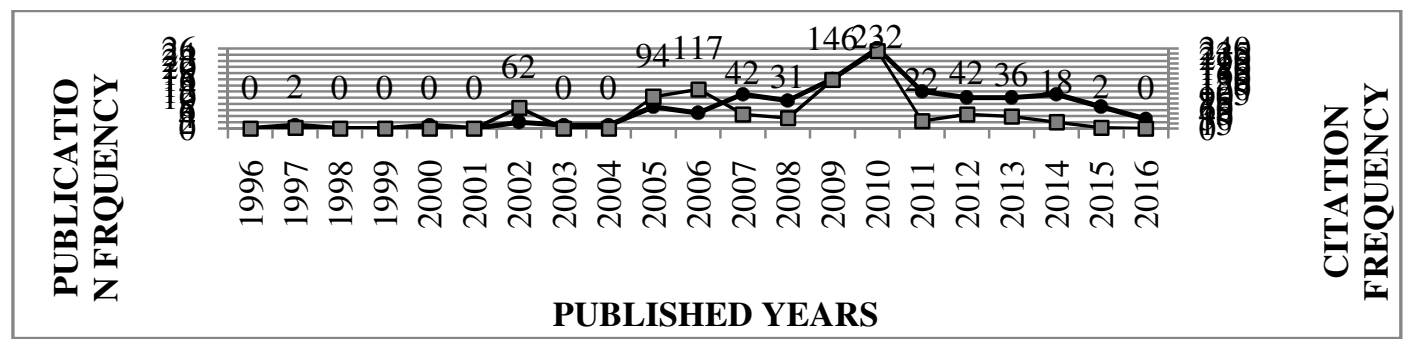

Figure 2. Citation rates per year (1996-2016)

\subsection{KEYWORD FREQUENCY}

As per Table 6, two lists of keywords frequency concerning the construction and ICT. Construction related keywords represented $(\mathrm{F}=16)$ while ICT related keywords represented $(\mathrm{F}=32)$. As demonstrated in Figure 3, a summation process of keywords correspondents was performed to decrease the keywords into 20 mainstream keywords. The highest frequency was for Information and Communication technology of $(\mathrm{F}=342)$ followed by construction industry of $(\mathrm{F}=137)$, followed by Construction, AEC, Building and Architecture of $(\mathrm{F}=78)$. The least frequency was for Design and communication, Artificial intelligence, Electronic commerce and Computer software of $(\mathrm{F}=6)$. 
International Journal of Managing Information Technology (IJMIT) Vol.8, No.3/4, November 2016

Table 6. Frequency of Keywords for construction and ICT

\begin{tabular}{|c|c|c|c|c|c|c|}
\hline Keyword (Construction) & $\mathrm{F}$ & Keyword (ICT) & & $\mathrm{F}$ & Keyword (ICT) & $\mathrm{F}$ \\
\hline Construction Companies & 13 & Information And Communication & Technoloaies & 8 & Virtual Realitv & 11 \\
\hline Construction Industry & 103 & Information And Communication & Technology & 41 & Building Information Model & 10 \\
\hline Construction Manaqement & 10 & Information And Communications & Technoloav & 17 & Innovation & 10 \\
\hline Construction Process & 9 & Information Technoloav & & 108 & Artificial Intelliqence & 7 \\
\hline Architectural Desian & 18 & INformation And Communication & Technoloaies & 4 & Desian And Construction & 6 \\
\hline Structural Design & 9 & ICT & & 23 & Electronic Commerce & 6 \\
\hline Construction Sites & 6 & Information Svstems & & 14 & Buildina Information & 6 \\
\hline Construction Firms & 6 & Information Svstem & & 6 & Computer Aided Desian & 6 \\
\hline Contractors & 6 & Information Management & & 21 & Computer Software & 6 \\
\hline Architecture . Enqineerina . And & 6 & Proiect Manaqement & & 48 & Internet & 6 \\
\hline
\end{tabular}

\subsection{AUTHORS FREQUENCY}

Table 7 demonstrates the chronological appearance of the contributing authors of the 68 research endeavours along with the year of publication, total citation (TC) and the percentage of occurrence. Obviously, year 2010 scored the highest publication rate with $(\mathrm{TC}=232,27.4 \%)$ and including 27 authors. This is followed by year 2009 with $(\mathrm{TC}=146,17.3 \%)$, followed by year 2006 with (TC=117, 13.8\%), year 2005 with (TC=94, 11.1\%), followed by years 2002, 2007, 2012, 2013, 2008, 2011, 2014, 1997 and 2015 with $(\mathrm{TC}=2-62,0.2 \%-7.3 \%)$, while the lowest score was for the years 1996, 1998, 1999, 2000, 2001, 2003, 2004 and 2016 with (TC=0, 0\%).

\section{Findings AND DiscuSSION}

\subsection{GEO-Spatial Coverage}

Table 8 highlights the frequency of cited ICT in the construction industry publications from the 25 different geographical regions between 1996 and 2016. From the 68 analyzed publications, the largest number of contributions was found in UK $(\mathrm{F} \%=15.5 \%)$, followed by USA $(\mathrm{F} \%=$ $13.8 \%)$, Sweden $(\mathrm{F} \%=10.3 \%)$, Hong Kong $(\mathrm{F} \%=6.9 \%)$, while Australia, Denmark, Finland and Turkey scored $(\mathrm{F} \%=5.17 \%)$ and the other remaining countries scored below the average of $(\mathrm{F} \%=4.11 \%)$. The results in Table 8 indicate that the first eight countries lead the most cited research in ICT in construction, followed by 18 countries of cited but low percentage rates.

Table 7. Authors distribution per year and citation rate

\begin{tabular}{|c|c|c|c|c|c|c|c|}
\hline $\mathrm{Y}$ & $\mathrm{TC}$ & $\%$ & Authors & $\mathrm{Y}$ & $\mathrm{TC}$ & $\%$ & Authors \\
\hline 2010 & 232 & 27.4 & $\begin{array}{l}\text { Froese T.M.; Jardim-Goncalvesand Grilo; Jacobsson and Linderoth; } \\
\text { Berente et al.; Perkinson et al.; Ajam et al.; Adriaanse et al.; Polat and } \\
\text { Donmez; Rezgui and Miles; Tang et al.; Chien and Barthorpe; Lam et } \\
\text { al.; Hallier and Baralou E.; Zhu et al.; Ahmad et al.; Alam et al.; } \\
\text { Charbonneau and Cechova; Fadiya et al.; Kinawy and El-Diraby; } \\
\text { Latorre et al..; Mehta A.; Ozumba et al.; Prinsloo and Mthembu; Rad }\end{array}$ & $\begin{array}{r}199 \\
7\end{array}$ & 2 & 0.2 & $\begin{array}{l}\text { Anumba and } \\
\text { Duke }\end{array}$ \\
\hline 2009 & 146 & 17.3 & $\begin{array}{l}\text { Dave and Koskela.; Ahuja et al.; Benjaoran V.; Sher et al.; Şahin and } \\
\text { Kurum; Suman et al.; Brewer and Gajendran; Ekholm and Molnár; } \\
\text { Han and Froese; Eberhardt et al.; Filos E.; Gomez C.P.; Hurst A.G.; } \\
\text { Ozumba and Shakantu: Rezgui and Miles }\end{array}$ & $\begin{array}{r}201 \\
5\end{array}$ & 2 & 0.2 & $\begin{array}{l}\text { Chen et al.; } \\
\text { Akanmu and } \\
\text { Anumba; de } \\
\text { Lima et al.: Leon }\end{array}$ \\
\hline
\end{tabular}


International Journal of Managing Information Technology (IJMIT) Vol.8, No.3/4, November 2016

\begin{tabular}{|c|c|c|c|c|c|c|c|}
\hline 2006 & 117 & 13.8 & $\begin{array}{l}\text { Bowden et al.; Penttilä H.; Rankin and Luther; Chaisuparasmikul P.; } \\
\text { Mediavilla et al. }\end{array}$ & $\begin{array}{r}199 \\
6 \\
\end{array}$ & 0 & 0.0 & \\
\hline 2005 & 94 & 11.1 & $\begin{array}{l}\text { Acar et al..; Peansupap and Walker; Lessing et al.; Graham and } \\
\text { Thomas; Bellamy et al...; Matipa and Siamuzwe; Oloke et al. }\end{array}$ & $\begin{array}{r}199 \\
8 \\
\end{array}$ & 0 & 0.0 & \\
\hline 2002 & 62 & 7.3 & Anumba et al.; Hassan and McCaffer & 199 & 0 & 0.0 & \\
\hline 2007 & 42 & 5.0 & $\begin{array}{l}\text { Oladapo A.A.; Hua G.B.; Nielsen and Koseoglu; Benza et al.; Ahmad } \\
\text { and Sein; Beyene et al.; Nielsen et al.; Paterson et al.; Soeiro A.; Xue }\end{array}$ & $\begin{array}{r}200 \\
0\end{array}$ & 0 & 0.0 & Menzel K. \\
\hline 2012 & 42 & 5.0 & $\begin{array}{l}\text { Chen et al.; Jacobsson and Linderoth; Pathirana et al.; Shin Y., Shin } \\
\text { D.-H.; Barnes S.-A.; Biorngrim et al.; Lee and Dossick; Li et al.; Riaz }\end{array}$ & $\begin{array}{r}200 \\
1\end{array}$ & 0 & 0.0 & \\
\hline 2013 & 36 & 4.3 & $\begin{array}{l}\text { Davies and Harty; Aguilar and Hewage; Arnold and Javernick-Will; } \\
\text { Jensen and Jóhannesson; Leem and Kim; Zhang and Ng; Alkalbani et } \\
\text { al.; Barbosa et al.; Liu et al.; Liu and Li }\end{array}$ & $\begin{array}{r}200 \\
3\end{array}$ & 0 & 0.0 & Goldsmith et al \\
\hline 2008 & 31 & 3.7 & $\begin{array}{l}\text { Dehlin and Olofsson; Molony T.; Zavadskas and Kaklauskas; } \\
\text { Keraminiyage et al.; Mitchell P.; Douglas et al.; Love et al.; Nassif } \\
\text { and Mangin; Ozumba and Shakantu }\end{array}$ & $\begin{array}{r}200 \\
4\end{array}$ & 0 & 0.0 & Gavin et al. \\
\hline 2011 & 22 & 2.6 & $\begin{array}{l}\text { Evia C.; Wong and Lam; Christiansson et al.; Al-Neshawy et al.; Riaz } \\
\text { et al.; Alaghbandrad et al.; Aziz et al.; Dolenc and Klinc; El Ghazali et } \\
\text { al.; Koseoglu O.; Linderoth et al.; Wu et al. }\end{array}$ & $\begin{array}{r}201 \\
6\end{array}$ & 0 & 0.0 & $\begin{array}{l}\text { Ikediashi and } \\
\text { Ogwueleka; } \\
\text { Park et al.; } \\
\text { Solnosky R.L. }\end{array}$ \\
\hline 2014 & 18 & 2.1 & $\begin{array}{l}\text { Inyim et al.; Lu Y et al.; Lin et al.; Oses et al.; Solnosky R.L.; Wang et } \\
\text { al.; Mahamadu et al.; Mesároš et al.; Toma et al.; van der Vlist et al.; }\end{array}$ & & & & \\
\hline
\end{tabular}

Table 8. Frequency of publications in each geographical location between 1996 and 2016

\begin{tabular}{llllllll}
\hline Location & $(\mathrm{F} \%)$ & Location & $(\mathrm{F} \%)$ & Location & $(\mathrm{F} \%)$ & Location & $(\mathrm{F} \%)$ \\
\hline Australia & & Italy & 1.72 & Portugal & 1.72 & Thailand & 1.72 \\
Canada & 3.45 & Korea & 3.45 & Singapore & 1.72 & Turkey & 5.17 \\
China & 1.72 & Lithuania & 1.72 & Slovenia & 1.72 & U.K & 15.5 \\
Denmark & 5.17 & Netherlands & 1.72 & Spain & 3.45 & USA & 13.8 \\
Finland & 5.17 & Nigeria & 1.72 & Sweden & 10.3 & & \\
Hong Kong & 6.9 & Norway & 1.72 & Taiwanese & 1.72 & & \\
Iceland & 3.45 & Oman & 1.72 & Tanzania & 1.72 & &
\end{tabular}

\subsection{Publication TyPe EMPLOYED}

Two sets of articles and papers were categorized based on the type of publication. The data presented in Table 2 illustrates that the vast majority of the publications are Journal articles $(\mathrm{F}=$ $84, \mathrm{~F} \%=42 \%)$, followed by Conference proceeding papers of $(\mathrm{F}=81, \mathrm{~F} \%=41 \%)$. The large number of research articles or papers clearly indicates the significance of the ICT technologies area in the construction industry and that most researchers are focused on developing and proposing Construction-related ICT solutions to many problems within the construction industry.

\subsection{RESEARCH METHODS EMPLOYED}

As per Table 9, nine research methods were employed in the selected articles and papers. The majority employed Case study of $(\mathrm{F}=27, \mathrm{~F} \%=37.5 \%)$ followed by questionnaire of $(\mathrm{F}=12, \mathrm{~F} \%=$ $16.7 \%)$, a survey questionnaire of $(\mathrm{F}=9, \mathrm{~F} \%=12.5 \%)$. Respectively, the other mentioned methods included interview, theoretical/conceptual, analytical, method, experiment and finally pilot study of $(\mathrm{F}=1-7, \mathrm{~F} \%=1.4 \%-9.7 \%)$.

Table 9. Research methods employed in articles and papers between 1996 and 2016

\begin{tabular}{ccccccccc}
\hline Analytical & $\begin{array}{l}\text { Case } \\
\text { study }\end{array}$ & Questionnaire & $\begin{array}{l}\text { Survey } \\
\text { Questionnaire }\end{array}$ & $\begin{array}{l}\text { Theoretical/ } \\
\text { Conceptual }\end{array}$ & interview & method & Pilot Study & Experiment \\
\hline 5 & 27 & 12 & 9 & 6 & 7 & 2 & 1 & 2 \\
$6.9 \%$ & $37.5 \%$ & $16.7 \%$ & $12.5 \%$ & $8.3 \%$ & $9.7 \%$ & $2.8 \%$ & $1.4 \%$ & $2.8 \%$
\end{tabular}


International Journal of Managing Information Technology (IJMIT) Vol.8, No.3/4, November 2016

\subsection{CONSTRUCTION TASKS IDENTIFIED}

From the selected articles and papers, Table 10 demonstrates the identification of 22 sets of construction Tasks including, Business process and strategy (BPS), Communication, collaboration and information sharing (CCIS), Cost, budget, financial, accounting and estimation (C), data and information modeling (DM), Decision making (DM), Design drawing, integration and optimization (D), Document management (DCM), E-commerce (EC), Educational and training (ET), Environmental (EN), HR management (HM), Knowledge management (KM), Marketing and presentation (MM), Production, performance and quality assurance (QA), Project planning and management (PM), Safety, Health and maintenance (S) and another subset of 6 proposals including, Delineation of digital images, Digital city, Standardization, Task management, Time saving and Research\& development. The following is a discussion of the identified Tasks.

Table 10. The Construction Tasks

\begin{tabular}{|c|c|c|c|}
\hline Author & Construction Task & Author & Construction Task \\
\hline Pathirana et al. & Collaboration & Berente et al. & Design/ \\
\hline Shin & Collaboration & Wong and Lam & Design \\
\hline Christiansson et al. & Collaboration & Oladapo A.A. & Design \& Drawing \\
\hline Rezgui and Miles & Collaboration & Anumba et al. & Design Integration \\
\hline Tang et al. & Collaboration & Invim & Design optimization \\
\hline Jardim-Goncalves and Grilo & Collaboration & Chien and Barthorpe & Design and Drawing \\
\hline Sher et al. & Collaboration & Al-Neshawy et al. & Environmental \\
\hline Penttilä $\mathrm{H}$. & Communication & Sahin and Kurum & Environmental \\
\hline Amold and Javemick-Will & Communication & Jacobsson and Linderoth & Environmental \\
\hline Peansupap & Communication \& Information sharing & Tang et al. & Document Management \\
\hline Nielsen and Koseoglu & Communication Collaboration & Chien and Barthorpe & Document Management \\
\hline Molonv T. & Communication\& Information sharing & Hassan and McCaffer & E-commerce \\
\hline Oladapo A.A. & Communication\& Information sharing & Jacobsson and Linderoth & E-commerce \\
\hline Jacobsson and Linderoth & Communication\& Information sharing & Chaisuparasmikul P. & Data and information \\
\hline Hassan and McCaffer & Communication\& Information sharing & Invim & Data and Information \\
\hline Anumba and Duke & Coordination of virtual models & Zhu et al. & Educational/Training \\
\hline Jensen and Jóhannesson & Information Sharing & Keraminivage et al. & Educational/Training \\
\hline Zhang and $\mathrm{Ng}$ & Information Sharing & Wang et al. & Educational/Training \\
\hline Wong and Lam & Information sharing & Evia $\mathrm{C}$ & Educational/Training \\
\hline Suman et al. & Business Process Reengineering (BPR) & Zavadskas and Kaklauskas & Decision making \\
\hline Hua G.B. & Business strategy & Chen et al. & Decision making \\
\hline Bowden et al & Cost & Rankin and Luther & Decision-making \\
\hline Chien and Barthorpe & Cost & Jacobsson and Linderoth & Decision-making \\
\hline Dehlin and Olofsson & Cost & Chien and Barthorpe & Knowledge Management \\
\hline Benjaoran V. & Cost & Lamet al & Knowledge Management \\
\hline Jacobsson and Linderoth & Cost & Graham and Thomas & Knowledge Management \\
\hline Wong and Lam & Cost & Zhang and $\mathrm{Ng}$ & Knowledge Management \\
\hline Jacobsson and Linderoth & Cost & Tang et al. & Knowledge Management \\
\hline Hassan and McCaffer & Cost & Hassan and $\mathrm{McCaffer}$ & Quality Assurance (QA) \\
\hline Oladapo A.A. & Cost & Lessing et al. & Production (Agile \\
\hline Froese & Project Management & Davies and Harty & Performance \\
\hline Sahin and Kurum & Project Management & Evia C. & Safety and Health \\
\hline Alkalbani et al. & Project Management & Benza et al. & Safety and Maintenance \\
\hline Han and Froese & Project Management & Lin et al. & Safety and Health \\
\hline Azhar et al. & Project Management & Riaz et al. & Safety and Health \\
\hline Perkinson et al. & Project management & Bowden et al & Safety and Maintenance \\
\hline Rankin and Luther & Project management & Leem and Kim & Safety and welfare (U- \\
\hline Lamet al & Project management & Polat and Donmez & Marketing Management \\
\hline Chien and Barthorpe & Project Management & Oladapo A.A. & Presentation \\
\hline Dave and Koskela & Project Management & Lamet al & HR Management \\
\hline Jacobsson and Linderoth & Project Planning & Chien and Barthorpe & HR Management \\
\hline Hassan and McCaffer & Project Planning & Jacobsson and Linderoth & Time savings \\
\hline Oladapo A.A. & Project Planning & Oses et al. & Delineation of digital \\
\hline Ekholm and Molnár & Research \& Development & Brewer and Gajendran & Standardization and \\
\hline & & Solnosky R.L. & Task Management \\
\hline
\end{tabular}

\subsection{ICT TECHNOLOGY IDENTIFIED}

In the selected articles and papers, Table 11 demonstrates the identification of 21 set of ICT 
Technologies, including, Web-based biometric, cloud computing and cyber physical systems (WB), BIM based technologies (BB), ICT (not identified specifically in research), Video Conferencing (VC), Virtual Reality (VR), CAD and 3D CAD (C), Mobile computing, phones and wireless technology (MW), Information systems (I), Decision based (D), Knowledge and information management (K), Computer based learning and training (CBT), Tracking technologies including GIS, GPS, Optical recognition, Telematics and RFID (TT), Simulation and analysis (S) and another 7 other sets including, Access and XML, OLAP, SOA, Genetic Algorithms, IPD, UCD and IFC. The following is a discussion of the identified ICT Technologies.

\subsection{TEChNOLOGY W.R.T TASKS}

This section discusses the previously determined technologies w.r.t. Construction tasks.

\section{WEB- BASED TECHNOLOGY (WB)}

According to [8], Web- based technologies provide a platform to manage and share construction information by getting rid of paper documents, improving access to data, allowing common documents between agents in different locations, eliminating discrepancy and misunderstanding in the versions of documents, and recording data in a multimedia format. A Web-based system uses a centralized information integration approach through a shared web server or a central database. Empirical findings reveal the availability of 16 web-based technologies spanning 7 construction tasks. In a questionnaire survey of the Taiwanese construction industry, [16] used the web-based internet for the (CCIS) construction Task. The findings revealed that e-mail as an internal and external communication tool and 58.8\% of the respondents used an Intranet for internal communication. Similarly, in a Swedish case study, [17] revealed the usage of e-mail and mobile phones for a (CCIS) construction Task. Other research works for (CCIS) construction Task include [18] who studied the business and ICT trends in the European LSE construction industry, [19] who studied the factors affecting ICT diffusion of three Australian construction contractors, [20] who investigated the use of ICT in the Nigerian construction industry revealing that the internet communications was one of the main uses of ICT in the construction industry, In Hong Kong, [21] showed that $92 \%$ of respondents used intranet internally and $79 \%$ used extranet externally for communication, respectively. $27 \%$ of the use of web-based platform was for internal communication and $24 \%$ for external information exchange. According to [22], Cloud computing is a style of computing at which virtualized resources are provided as a service over the Internet. Thus, the implementation of BIM under the Cloud Computing paradigm (i.e. a type of web-based technology) promotes the B\&C industry to achieve the single electronic market. Web-based intelligent \& biometric technology was found in the work of [23]. Also, according to a study on the Omani contractors, [24] showed that one of the main areas for ICT investment to satisfy the (PM) Task was web-based technologies including, email, database and web browsing.

Table 11. Authors' Publications and corresponding ICT Technologies

\begin{tabular}{|l|l|l|l|}
\hline \multicolumn{1}{|c|}{ Author } & \multicolumn{1}{|c|}{ ICT Technology } & \multicolumn{1}{c|}{ Author } & \multicolumn{1}{c|}{ ICT Technology } \\
\hline Penttilä H. & BIM-based & Nielsen and Koseoglu & Mobile Computing \\
\hline Davies and Harty & BIM-based & Molony T. & Mobile Phones \\
\hline Solnosky R.L. & BIM-based & Suman et al. & Mobile Technology \\
\hline
\end{tabular}


International Journal of Managing Information Technology (IJMIT) Vol.8, No.3/4, November 2016

\begin{tabular}{|c|c|c|c|}
\hline Jensen and & BIM-based & Riaz et al. & Mobile Technology \\
\hline Jacobsson and & BIM-based & Bowden et al & Mobile technology \\
\hline Inyim & BIM-based & Nielsen and Koseoglu & Wireless Communication \\
\hline Wang et al. & BIM-based & Leem and Kim & Wireless \\
\hline Chen et al. & BIM-based & Inyim & Simulation \\
\hline Chaisuparasmikul P. & BIM-based & Froese & Simulation and analysis \\
\hline Berente et al. & 3D CAD & Tang et al. & Knowledge \&IM practice \\
\hline Ekholm and Molnár & 3D CAD & Graham and Thomas & Knowledge Management \\
\hline Brewer and & CAD & Zhang and $\mathrm{Ng}$ & Knowledge Management \\
\hline Alkalbani et al. & CAD & Chien and Barthorpe & Knowledge Management \\
\hline Chien and Barthorpe & CAD & Azhar et al. & Integrated Prjct deliv \\
\hline Anumba et al. & CAD & Lin et al. & User Centred Design \\
\hline Evia $\mathrm{C}$. & Computer based Training & Froese & IFC \\
\hline Keraminiyage et al. & Virtual learning environment & Chien and Barthorpe & Video Conferencing \\
\hline Zhu et al. & Computer-mediated learning & Hassan and McCaffer & Video Conferencing \\
\hline Benjaoran V. & MS Access and XML & Dehlin and Olofsson & Virtual Reality \\
\hline Froese & Online analytical Processing & Sher et al. & Virtual Reality \\
\hline Rezgui and Miles & Service-oriented architecture & Christiansson et al. & Virtual Reality \\
\hline Jacobsson and & Decision-based & Ekholm and Molnár & Virtual Reality \\
\hline Rankin and Luther & Decision-making & Chaisuparasmikul $\mathrm{P}$. & Virtual Reality \\
\hline Benza et al. & DSs & Chien and Barthorpe & Virtual Reality \\
\hline Leem and Kim & Tracking technologies (GIS and & Chien and Barthorpe & Web- based \\
\hline Bowden et al & Tracking technologies (GIS and & Jacobsson and & Web- based \\
\hline Perkinson et al. & Tracking technologies (GPS) & Hassan and McCaffer & Web- based \\
\hline Benza et al. & Tracking technologies (Optical Rn) & Zavadskas\&Kaklausk & Web- based (Intelligent\& \\
\hline Benza et al. & Tracking technologies (Telematics & Peansupap & Web-based \\
\hline Riaz et al. & Tracking technologies (RFID) & Oladapo A.A. & Web-based \\
\hline Hua G.B. & ICT & Polat and Donmez & Web-based \\
\hline Wong and Lam & ICT & Tang et al. & Web-based \\
\hline Zahin and Kurum & ICT & Lam et al & Web-based \\
\hline Shin & ICT & Pathirana et al. & Web-based \\
\hline Lessing et al. & ICT & Nielsen and Koseoglu & Web-based \\
\hline Azhar et al. & ICT & Alkalbani et al. & Web-based \\
\hline Han and Froese & Information System & Benza et al. & Web-based (GIS) \\
\hline Al-Neshawy et al. & Information System & Dave and Koskela & Web-based (knowledge \\
\hline Riaz et al. & Information system & Jardim-Goncalves and & Web-based (Cloud \\
\hline Alkalbani et al. & Project Management & Anumba and Duke & Web-based (Cyber \\
\hline Arnold and & Project Management Systems & & \\
\hline
\end{tabular}

\section{BIM-BASED TECHNOLOGY (BB)}

[25] describe BIM as a digital environment that is used in the design and preconstruction stages of a building project and its components which retrieves information of a three-dimensional (3D) entity model by multiple different project team members during the project. Empirical findings reveal the penetration of 10 BIM- based technologies for different Construction Tasks. [26] 
proposed Building product modelling based on building information modelling (BIM) technology to manage all design and construction issues within the IT-oriented building projects and process environments for (CCIS) construction Task. In a survey to measure beliefs and use of BIM amongst employees of a construction contracting company in UK, [25]found for (P) construction Task, BIM was broadly favorable and provided comparable benchmarks for research with other samples and technology definitions. Furthermore, to implement the BIM technology in Denmark and Iceland for better quality buildings and increased productivity, [27] found that BIM was limited in the Icelandic companies compared to the other Nordic countries. Additionally, [28] mentioned that within the project studied, a 3D-based building and information model (BIM) was adopted for (PM) Construction Task to support information and communication flows in the production process. Also, it was designed specifically to aid in the (DM) Task during the design stage of a construction project. According to [29], BIM and software interoperability were needed to facilitate information sharing and data integration (DM) and (CCIS) construction Tasks. BIM provided advanced building services through the use of tools in collaborative project.

\section{CAD AND 3D CAD TECHNOLOGY (C)}

According to [30], CAD technology (C) is used in the drafting and design of small and large types of buildings and may be used to design curves and figures in two-dimensional 2D or 3D space. Thus, the empirical findings reveal the penetration of (C) in 6 articles including, [31] who ran a project on architectural design Task (D) and shifted to 3D CAD technology (C) across participating design teams. They aimed to explore the technological shift and among a number of design firms to better understand the levels of ICT penetration. The study of [16] revealed that CAD (C) was one of the most useful technologies to improve the effectiveness of product design and drawing Task (D). Brewer and [32] employed (C) for Standardization and Protocols Task.

\section{COMPUTER BASED TRAining Technology (CB)}

According to [33], one technology of ICTs that could help Hispanic/Latino workers was the application of computer-based training (CBT) for safety purposes at work on an educational and training basis as an (ET) Task. Similarly, [34] discussed the (CB) technology through the development of a similarity measure to assess the knowledge structure of students and facilitate the evaluation of common understanding of students for the Educational (ET) Task.

\section{DECISION-BASED TECHNOLOGY (D)}

In a case study conducted by [35], decision-making (D) was aimed to measure the current level of ICT maturity within the construction industry and the cost savings (C). Decision-making tools predict whether or not implementation of a particular ICT would be a bad investment and what adoption rate would be required to turn a bad investment into a good investment. In an attempt to determine the most effective ICT Technologies to detect and monitor the hazardous material transportation on the road infrastructure between France and Italy, [36] presented a Decision Support System to minimize the hazardous material transportation risk and to improve the road infrastructure safety conditions (S) Task.

\section{TrACKING TEChNOLOGY (TT)}

A tracking system is used to observe the movement of persons or objects and provides a timely ordered sequence of respective location data to a model that depicts the motion on a display 
capability. Location tracking is a convergence of several technologies that can be merged to create systems. In South Korea, [37] studied the ubiquitous city service classification system by means of providing balanced city service ICT aiming to improve the quality of life of city people in terms of secure/safe social environment; safety (S) Task. Ubiquitous City referred to a city fully equipped with networks that integrates advanced IT based infrastructures and ubiquitous information services into the urban space. (TT) included the usage of GIS, GPS, and RFID. GIS stores, edits, analyzes, shares and displays geographical referenced information. GPS which enables a GPS receiver to determine its location, speed, and direction while RFID is a sensing technology that uses radio signals to identify objects from small sensor devices composed of RFID tags or transponders and RFID readers [37]. For vehicle/pedestrian safety and improved plant-related H\&S management, [38] presented an automatic identification and data collection (AIDC) technology to satisfy the needs of plant operators and safety managers; (S) Task, at which an RFID provided data storage and radio waves to wirelessly transmit the identity of a person.

\section{INFORMATION SYSTEM TECHNOLOGY (I)}

According to [8], (I) allows for collecting, processing, storing, and distributing information to support daily operations and enhance performance and competitiveness of construction firms. [38] demonstrated the presence of a management information system (I) to share information among different software applications technology to satisfy the needs of plant operators and safety managers; (S) Task. To develop a humidity and temperature monitoring network system for repaired concrete building facades, [39] proposed a Microsoft Visual Basic 6.0. system that runs on Microsoft Windows platforms. The RHT-MNS monitoring software was used to configure the RHT-MNS system, connect with the network controller, calculate humidity and temperature data and process the generated data into charts to meet the (EN) construction Task. On a case study approach, [40] proposed a framework for Project Information Management (I) so to manage construction project's information systems; (PM) Task.

\section{MOBILE COMPUTING AND WIRELESS TECHNOLOGY (MW)}

According to [41], (MW) allows an access to centrally stored information and decision makers of a construction project to remotely monitor the site and collect real-time data. Hence, investigate the application of Wireless networking in tunneling projects [42] examined the implementation of mobile technologies in the construction sector for real-time information access and improved collaboration of distributed teams; (CCIS) Task. [43] studied the role of Mobile Phones in Tanzania's informal construction sector in order to assess the applicability of government policy and Tanzania's small-enterprise development policy on the use of internet. Differently, in Slovenia, [44] examined the factors affecting the implementation of mobile information and communication technology to improve the performance of concrete construction companies in light of business process reengineering (BPS) Task. [45] mentioned the roles played by (MW) in many construction tasks including the use of RFID as a technology for accident reduction; (S) Task and the use of GIS and GPS technologies for waste reduction (S) and (EN) Tasks. Also, they mentioned the role of (MW) into operation and maintenance cost reduction which could be achieved through increasing the efficiency of maintenance personnel and the collection and provision of information during the building process.

\section{KNOWLEDGE AND INFORMATION MANAGEMENT (K)}

According to [46], $(\mathrm{K})$ is described as the process of creating, sharing, using and managing the 
knowledge and information of an organization. [47] identified current approaches to information evaluation based on interviews with five construction firms in comparison with three aerospace firms. The K\&IM practices included three distinct classifications: hardware and software. Hardware included databases, networks, servers, communication systems, phone and PDA, personal PCs while software included data and document management systems for (DM) construction Tasks, intranets, extranets, protocols, shared repositories, wikis, blogs, email, yellow pages, Web 2.0, XML tools and intelligent decision support systems for (CCIS) construction Tasks. [46] conducted a survey of 20 Irish construction companies, interviews with some personnel and then a case study research of a single company to assess suitability of the companies for the (K) technology. It was found that (K) systems best supported (KM) Tasks. To investigate the factors affecting individual knowledge-sharing intention in Hong Kong construction Teams, [48] found out that ICT had a significant effect on professionals' perceived behavioral control over knowledge sharing. Similarly in Hong Kong, [21] pointed out through an interview that a construction organization provided online collaboration and KM platform for exchanging, collaborating and sharing information among internal and external working parties.

\section{SimULATION AND ANALYSIS (S)}

In his paper, [49] introduced an extension and add on to the Autodesk Revit Architecture application at which it simulates (S) the environmental Impact of Construction during the design stage of a construction project; (D) Task. To support the (PM) Task, [50] suggested the information aggregators, acting as simulation techniques to allow users to define and work with the inter-relationships between the views and analyze inter-related information.

\section{VIDEO CONFERENCING (VC)}

Video is a set of telecommunication technologies which allow for the communication of two or more locations using a simultaneous two-way video and audio transmissions. [16] used VC for communication (CCIS) Tasks in the Taiwanese construction industry.

\section{ViRTUAL AND ViRTUAL REALITY TECHNOLOGY (VR)}

[41] describes (VR) technology as "a computer generated environment that can utilize visual, auditory and haptic (touch and force) channels for communication between a user and a computer". In other words, [16] saw it as a technology that enables interactive real-time viewing of three-dimensional data as a means of a communication tool. Empirical findings reveal the presence of 7 research works on VR. In Sweden, [51] presented a new evaluation model used by a multi-disciplinary working team throughout the process of assessing, planning, implementation and utilization of ICT investment (VR) in a construction project organization. VR was useful in the conceptual design; (D) Construction Task of the plant layout and in the detailed design phase. In Australia, [52] examined the use of ICT (3D Virtual environment) to facilitate design and/or construction team interactions (CCIS) Task. [53] proposed a Virtual Innovation in Construction project aiming to develop an ICT supported methodology which involves building end-users in a process with building designers, and to collect end-user requirements on the ultimate use of buildings. According to [54], some construction ICT developers identified eight development areas with high potential for improved productivity and quality through application of modern ICT including, Virtual reality (VR). [29] proposed a virtual model system framework that provides data collaboration, integration and sharing capabilities between CAD (D) Task; and other applications including, building code check, submission and compliance, energy 
performance simulation and prediction. According to a survey on VR, [16] found that VR represented $76 \%$ of the most useful tools in improving the effectiveness of marketing and communication besides the benefits of using VR in architectural design, training, sales and marketing tools.

\subsection{Technology And TASk Distribution}

Table 12 demonstrates the correspondence of the Construction Tasks without groupings and as literarily identified in the selected articles and papers with an average of 9\%. Hence, 13 tasks scored the highest percentage rates. Project management scored 36\%, HR Management scored $24 \%$, Communication \&Information sharing scored 21\%, Collaboration, Cost scored 18\%, Design,

Table 12. Distribution of ICT Technologies per Construction Tasks

\begin{tabular}{|c|c|c|c|c|c|c|c|c|c|c|c|c|c|c|c|c|c|c|c|c|c|c|c|c|c|c|c|c|c|c|}
\hline & \multicolumn{30}{|c|}{ Construction Task } \\
\hline $\begin{array}{c}\text { ICT } \\
\text { Technology }\end{array}$ & 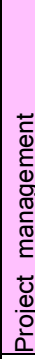 & 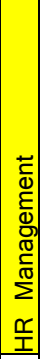 & 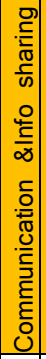 & 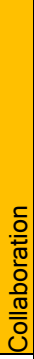 & 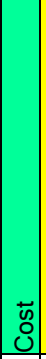 & $\begin{array}{l}.5 \\
.05 \\
0 \\
0 \\
\end{array}$ & 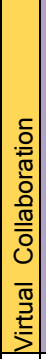 & \begin{tabular}{|c|} 
\\
\\
$\overline{0}$ \\
0 \\
.0 \\
$\frac{0}{\pi}$ \\
$\frac{0}{0}$ \\
$\overline{0}$ \\
\end{tabular} & 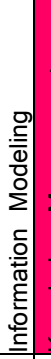 & 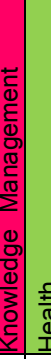 & 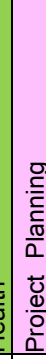 & 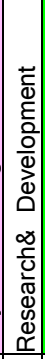 & $\begin{array}{l} \\
8 \\
0 \\
0 \\
0 \\
\tilde{0} \\
0 \\
0 \\
0 \\
0\end{array}$ & 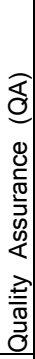 & 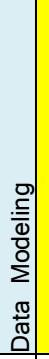 & 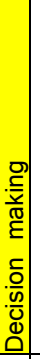 & $\begin{array}{l} \\
\frac{7}{0} \\
\frac{\pi}{0} \\
\frac{0}{0}\end{array}$ & & 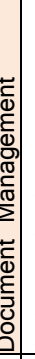 & 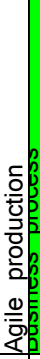 & & 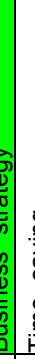 & & & 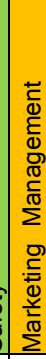 & \begin{tabular}{|l|} 
\\
\\
\\
0 \\
0 \\
0 \\
0 \\
0 \\
0 \\
0 \\
0 \\
0 \\
0 \\
0 \\
0
\end{tabular} & 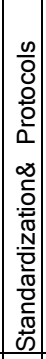 & 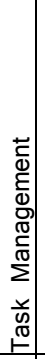 & 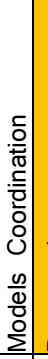 & 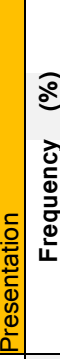 \\
\hline Web-based & $x$ & $x$ & $x$ & $x$ & $x$ & $x$ & $x$ & & & & $x$ & & $x$ & $x$ & & $x$ & & 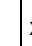 & & & & & & & $\mathrm{x}$ & & & & $x$ & $x 44$ \\
\hline BIM based & & & $x$ & $x$ & $x$ & & & & $x$ & & $x$ & & & & $x$ & & & & & & & & $\mathrm{x}$ & & & $x$ & & $x$ & & 28 \\
\hline ICT & $x$ & & $x$ & $\mathrm{x}$ & $x$ & $x$ & & & & & & & & & & & & 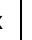 & & $x$ & $\mathrm{r}$ & & & & & & & & & 25 \\
\hline Video & $x$ & $x$ & $x$ & & $x$ & & & & $x$ & $x$ & $x$ & & $x$ & $\mathrm{x}$ & & & & & & & & & & & & & & & & 25 \\
\hline Virtual Reality & & $x$ & & $x$ & $x$ & & $x$ & & $x$ & $x$ & & $x$ & & & $x$ & & & & & & & & & & & & & & & 22 \\
\hline CAD & $x$ & $x$ & & & & $x$ & & & $x$ & $x$ & & $x$ & & & & & & & & & & & & & & & $x$ & & & 19 \\
\hline $\begin{array}{l}\text { Mobile } \\
\text { Technology }\end{array}$ & & & $x$ & & & & & & & $\mathrm{x}$ & & & & & & & & & & & & & & $x$ & & & & & & 13 \\
\hline $\begin{array}{l}\text { Information } \\
\text { System }\end{array}$ & $x$ & $x$ & & & & & & & & $\mathrm{x}$ & & & & & & & & & & & & & & & & & & & & 13 \\
\hline Decision based & & & & & & & $x$ & & & & & & & & & $x$ & & & & & & $\mathrm{x}$ & & & & & & & & 9 \\
\hline Knowledge Mgt & & $x$ & & & & & & & $x$ & $x$ & & & & & & & & & 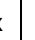 & & & & & & & & & & & 9 \\
\hline Project Mgt & $x$ & & $x$ & & & & & & & & & & & & & & & & & & & & & & & & & & & 6 \\
\hline $3 D$ & & & & & & $x$ & & & & & & $x$ & & & & & & & & & & & & & & & & & & 6 \\
\hline GPS & $x$ & & & & & & & & & & & & & & & & $\mathrm{x}$ & & & & & & & & & & & & & 6 \\
\hline $\begin{array}{l}\text { Computer- } \\
\text { mediated }\end{array}$ & & & & & & & $x$ & $x$ & & & & & & & & & & & & & & & & & & & & & & 6 \\
\hline Simulation & $x$ & & & & & & & & $x$ & & & & & & & & & & & & & & & & & & & & & 6 \\
\hline UCD & & $x$ & & & & & & & & $\mathrm{x}$ & & & & & & & & & & & & & & & & & & & & 6 \\
\hline RFID & & $x$ & & & & & & & & $\mathrm{x}$ & & & & & & & & & & & & & & & & & & & & 6 \\
\hline Simulation & $x$ & & & & & & & & $\mathrm{x}$ & & & & & & & & & & & & & & & & & & & & & 6 \\
\hline
\end{tabular}


International Journal of Managing Information Technology (IJMIT) Vol.8, No.3/4, November 2016

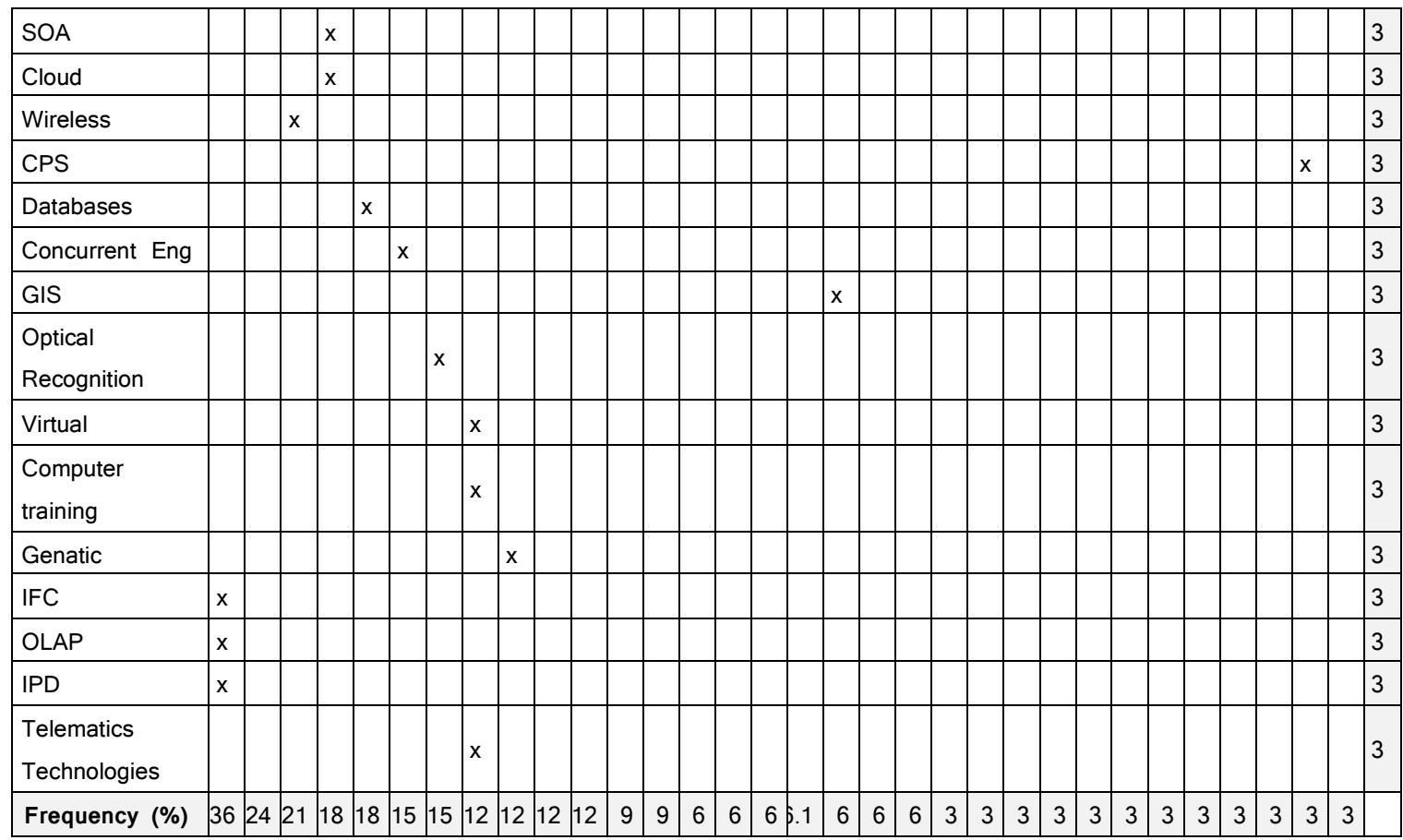

Virtual Collaboration scored 15\%, Educational, Information Modeling, Knowledge Management, Health scored 12\%, Project Planning, Research\& Development scored 9\%. Due to their minimal availability, the remaining 19 tasks scored between 3\%- 6\% which implies that future research should focus on them. Findings imply that the most focus of construction tasks is shifted towards the managerial sides (i.e. Project management, HR Management, and Communication \&Information sharing) followed by financial side (i.e. Cost), then followed by Collaboration and communication sides (i.e. Collaboration, Design and Virtual Collaboration), while other tasks were executed for almost individual purposes and concerns or very specific occasions (i.e. safety and environmental, knowledge management, etc.). Similarly, Table 12 demonstrates the availability of 33 ICT Technologies which were identified in the selected articles and papers, 10 ICT Technologies out of which scored the highest. Web-based scored $44 \%$, BIM based technologies scored 28\%, ICT (not identified specifically in research), Video Conferencing scored 25\%, Virtual Reality scored 22\%, CAD scored 19\%, both Mobile technology and information systems scored $13 \%$ and both Decision based and Knowledge management scored 9\%. The remaining 23 tasks minimally appeared and scored between 3\%- 6\% which implies that future research should focus on them. This implies that due to the full reliance nowadays on the internet, Web based ICT technologies constituted the highest rates.

\section{CONCLUSION}

This paper aimed to reveal the current state of ICT applications, technology and tasks within construction published in a number of key journals and papers which were extracted from the Scopus database, thereby focusing on the historical trends and current patterns in the use of different types of ICT's technologies, applications and tasks in the construction industry. Using a systematic review of 68 papers, this paper has primarily analyzed the type of ICT technologies employed in construction industry related research studies between 1996 and 2016, thus fulfilling the indicated aim of this research in section 1.1. Clearly, Figure 1, Table10 and Table11 indicate 
the historical trends and current patterns in the number of papers published on ICT and the type of ICT applications and technologies employed/discussed in each paper. Moreover, 33 ICT technologies were identified in the selected articles and papers. 10 out of which scored the highest percentage rates. This includes, Web-based which scored the highest score of $44 \%$, followed by BIM based technologies, ICT, Video Conferencing, Virtual Reality scored, CAD, Mobile technology and information systems, Decision based and Knowledge management scored between 9\%-28\%. The remaining 23 ICT technologies scored between 3\%-6\%. Moreover, as per Table10, 32 ICT tasks were identified in the selected articles and papers. 13 out of which scored the highest percentage rates. This includes Project management which scored the highest score of $36 \%$, followed by HR Management, Communication \&Information sharing, Collaboration, Cost, Design, Virtual Collaboration, Educational, Information Modeling, Knowledge Management, Health, Project Planning and Research\& Development which all scored between 9\%-24\%. The remaining 19 tasks scored between 3\%- 6\%. Furthermore, employing an established methodology, the paper examined a number of dimensions in the 68 papers analyzed: publications in each year; geographic location of the paper; type of publication; research methods employed; type and number of ICT technologies employed; citation analysis; type of journal; and the context in which each article was published. This study has analyzed a substantial number of papers compared to existing review articles on the theme of "ICT in Construction". The intention in conducting this investigation was to provide a useful and usable resource of information for future researchers in the field of ICT in construction. The findings of this study clearly indicate diversity in the number of papers published on the different types of ICT technologies from 1996 to 2016, although there is a fluctuating decline in the number of papers since 2002, resulting in fewer publications in 2015. However, increasing support to the construction industry given by the global corporations in the future is anticipated to encourage researchers and academics to publish more papers on different types of ICT technologies in the construction industry from 2016 onwards.

\section{REFERENCES}

[1] C. Carter, T. Hassan, and M. Merz, "The eLegal project: specifying legal terms of contract in ICT environment", International Journal of Information technology in Construction, 6, 136. 2001.

[2] M. Sarshar, U. Isikdag, "A survey of ICT use in the Turkish construction industry", in Engineering, Construction and Architectural Management, 2004, 11(4), 238-247.

[3] A. Andrews, J. H. Rankin, and L. M. Waugh, "A framework to identify opportunities for ICT support when implementing sustainable design standards". Journal of Information technology in Construction, 11, 2006, 17-33.

[4] Y. Rezgui, A. Zarli, and C. J. Hopfe, "Editorial-Building Information Modeling Applications, Challenges and Future Directions", Journal of Information Technology in Construction, 14, 613-616. 2009.

[5] B. Erdogan, C. Abbott, and G. Aouad, "Construction in year 2030: developing an information technology vision," in Philosophical Transactions of the Royal Society of London A: Mathematical, Physical and Engineering Sciences, 368(1924), 3551-3565. 2010.

[6] A. Sextos, "ICT applications for new generation seismic design, construction and assessment of bridges." Structural Engineering International, 24(2), 173-183. 2014.

[7] E. O. Ibem and S. Laryea, "Survey of digital technologies in procurement of construction projects", Automation in Construction, 46, 11-21. 2014.

[8] M. Martínez-Rojas, N. Marin, and M.A. Vila, "The role of information technologies to address data handling in construction project management." Journal of Computing in Civil Engineering, 04015064. 2015.

[9] R. Amor, M. Betts, G. Coetzee, and M. Sexton. "Information technology for construction: recent 
International Journal of Managing Information Technology (IJMIT) Vol.8, No.3/4, November 2016

work and future directions", 7(16), 245-258. 2002.

[10] Y.S. Ampofo, B. Bizimana, J. Mbuthi, I. Ndayambaje, N. Ogetta, and A.J. Orodho, "Information Communication Technology Penetration and its Impact on Education: Lessons of Experience from Selected African Countries of Ghana, Kenya and Rwanda“, Journal of Information Engineering and Applications, 4 (11), pp.84-95. 2014.

[11] N. Mutesi, "Application of ICT in the Construction Industry in Kampala" in Advances in Engineering and Technology: Contribution of Scientific Research in Development: Proceedings of the Second International Conference on Advances in Engineering and Technology, Kampala. Makrere University.Tanzania. 2009.

[12] B. Bjork, "A framework for discussing information technology applications in construction" in CIB Working Commission W78 workshop." Information Technology Support for Construction Process Re-engineering", Cairns, Australia, 1997.

[13] W. El-Ghandour and M. Al-Hussein. "Survey of information technology applications in construction", Construction innovation, 4(2), 83-98. 2004.

[14] J.M. Doherty. "A survey of computer use in the New Zealand building and construction industry". Electronic Journal of Information technology in Construction, Vol 2, 1-13. 1997.

[15] C. L. Perkinson and I. U. Ahmad. "Computing Technology Usage in Construction Contractor Organizations." In Fourth LACCEI International Latin American and Caribbean Conference for Engineering and Technology (LACCET'2006), Breaking Frontiers and Barriers in Engineering: Education, Research and Practice, 2006.

[16] H. J. Chien and S. Barthorpe. "The current state of information and communication technology usage by small and medium Taiwanese construction companies". Journal of Information Technology in Construction, 15(5), 75-85. 2010.

[17] M. Jacobsson and H. Linderoth. "The influence of contextual elements, actors' frames of reference, and technology on the adoption and use of ICT in construction projects: a Swedish case study". Construction Management and Economics, 28(1), 13-23. 2010.

[18] T. M. Hassan and R. McCaffer. "Vision of the large scale engineering construction industry in Europe". Automation in construction, 11(4), 421-437. 2002.

[19] V. Peansupap and D. Walker. "Factors affecting ICT diffusion: A case study of three large Australian construction contractors". Engineering, Construction and Architectural Management, 12(1), 21-37. 2005.

[20] Oladapo, A. A. "An investigation into the use of ICT in the Nigerian construction industry". Journal of Information Technology in Construction, 12(18), 261-277. 2007.

[21] P. T. Lam, F. W. Wong, and K. T. Tse,. "Effectiveness of ICT for construction information exchange among multidisciplinary project teams". Journal of Computing in Civil Engineering, 24(4), 365-376. 2009

[22] R. Jardim-Goncalves and A. Grilo. "SOA4BIM: Putting the building and construction industry in the Single European Information Space". Automation in Construction, 19(4), 388-397. 2010.

[23] E.K. Zavadskas and A. Kaklauskas. "Advanced information and communication technologies in construction". in The 25th International Symposium on Automation and Robotics in Construction ISARC-2008, 2008, 39-45.

[24] S. Alkalbani, Y. Rezgui, C. Vorakulpipat, and I.E. Wilson. "ICT adoption and diffusion in the construction industry of a developing economy: The case of the sultanate of Oman." Architectural Engineering and Design Management, 9(1), 62-75. 2013.

[25] R. Davies, and C. Harty. "Measurement and exploration of individual beliefs about the consequences of building information modelling use." Construction Management and Economics, 31(11), 11101127. 2013.

[26] H. Penttilä. "Describing the changes in architectural information technology to understand design complexity and free-form architectural expression". Journal of Information Technology, 19(29), 395-408. 2006.

[27] P.A. Jensen, P. A. and E.I. Jóhannesson. "Building Information Modelling in Denmark and Iceland. Engineering", Construction and Architectural Management, 20(1), 99-110. 2013.

[28] M. Jacobsson and H.C. Linderoth. "User perceptions of ICT impacts in Swedish construction 
International Journal of Managing Information Technology (IJMIT) Vol.8, No.3/4, November 2016

companies: 'it's fine, just as it is'. Construction management and economics, 30(5), 339-357. 2012.

[29] P. Chaisuparasmikul. "Bidirectional Interoperability Between CAD and Energy Performance Simulation Through Virtual Model System Framework.” in Proceedings: ACADIA, 2006, 12-15.

[30] G.E. Farin, J. Hoschek, and M.S. Kim. Handbook of computer aided geometric design. Elsevier. 2002.

[31] N. Berente, R. Baxter,and K. Lyytinen. "Dynamics of inter-organizational knowledge creation and information technology use across object worlds: the case of an innovative construction project." Construction Management and Economics, 28(6), 569-588. 2010.

[32] G. Brewer and T. Gajendran. "Emerging ICT trends in construction project teams: a Delphi survey." Journal of Information Technology in Construction, 14, 81-97. 2009.

[33] C. Evia. "Localizing and designing computer-based safety training solutions for Hispanic construction workers." Journal of Construction Engineering and Management, 137(6), 452-459. 2010.

[34] Y. Zhu, R. Zhang, and I. Ahmad. "Applying concept similarity to the evaluation of common understanding in multidisciplinary learning." Journal of Computing in Civil Engineering, 24(4), 335344. 2009.

[35] J. H. Rankin and R. Luther. "The innovation process: adoption of information and communication technology for the construction industry". Canadian Journal of Civil Engineering, 33(12), 15381546. 2006.

[36] M. Benza, C. Bersani, E. Garbolino, D. Giglio, S. Olampi, R. Sacile, and E. Trasforini. "A distributed information system prototype to detect and monitor the Hazardous Material Transport on the road in the territory of Nice-Imperia-Ventimiglia." WIT Transactions on The Built Environment, 2007, 94.

[37] C.S. Leem and B.G. Kim. "Taxonomy of ubiquitous computing service for city development." Personal and ubiquitous computing, 17(7), 1475-1483. 2013.

[38] Z. Riaz, D.J. Edwards, G. D. Holt, and T. Thorpe. "Data flow analysis of plant and equipment health and safety management." Journal of Engineering, Design and Technology, 9(2), 178-203. 2011.

[39] F. Al-Neshawy, J. Piironen, S. Peltola, E. Sistonen, and J. Puttonen. "Network system for assessing the moisture and thermal behaviour of repaired concrete building facades.", Journal of Information technology in Construction, Vol. 16, pg. 601-616. 2011.

[40] Z. Han, T. Froese. "Project Information Management in Mega Oil Sands Projects.". Building a Sustainable Future: pp. 71-80.pp. 71-80. 2009.

[41] A.P. Chassiakos. "The Use of Information and Communication Technologies in Construction." Civil Engineering Computations: Tools and Techniques. Saxe-Coburg Publications, Stirlingshire, UK, Chapter 5, pp 79-104, 2007.

[42] Y. Nielsen, and O. Koseoglu. "Wireless networking in tunnelling projects." Tunnelling and underground space technology, 22(3), 252-261. 2007.

[43] T. Molony. "The role of mobile phones in Tanzania's informal construction sector: The case of Dar es Salaam”. In Urban Forum, 2008. 19-2, pp. 175-186.

[44] N. Suman, D. Ursic, M. Psunder, and D. Veselinovic. "Mobile information and communication technology and management of business changes in construction companies in Slovenia." Systemic Practice and Action Research, 22(5), 397-411. 2009.

[45] S. Bowden, A. Dorr, T. Thorpe, and C. Anumba. "Mobile ICT support for construction process improvement." Automation in construction, 15(5), 664-676. 2006.

[46] B. Graham and K. Thomas. "An investigation into the development of knowledge management systems within the leading Irish construction companies.” In Khosrowshahi, F. (ed.), 21st Annual ARCOM Conference, 7-9 September 2005, School of Oriental and African Studies. Association of Researchers in Construction Management, 2005, Vol. 1, 499-508.

[47] L. C. Tang, Y. Zhao, S. Austin, M. Darlington, and S. Culley, S. "Codification vs personalisation: A study of the information evaluation practice between aerospace and construction industries." International Journal of Information Management, 30(4), 315-325. 2010.

[48] P. Zhang and F.F. Ng. "Explaining knowledge-sharing intention in construction teams in Hong Kong.” Journal of Construction Engineering and Management, 139(3), 280-293. 2013. 
International Journal of Managing Information Technology (IJMIT) Vol.8, No.3/4, November 2016

[49] P. Inyim, J. Rivera, and Y. Zhu. "Integration of building information modeling and economic and environmental impact analysis to support sustainable building design." Journal of Management in Engineering, 31(1), A4014002. 2014.

[50] T. M. Froese. "The impact of emerging information technology on project management for construction." Automation in construction, 19(5), 531-538. 2010.

[51] S. Dehlin, and T. Olofsson. "An evaluation model for ICT investments in construction projects." Journal of Information Technology in Construction, 13, 343-361. 2008.

[52] W. Sher, S. Sherratt, A. Williams, and R. N. Gameson. "Heading into new virtual environments: what skills do design team members need?.” Journal of Information Technology in Construction, 14, 17-29. 2009.

[53] P. Christiansson, K. Svidt, K.B. Sørensen, and U. Dybro. "User participation in the building process.” Journal of Information Technology in Construction, 16, 309-334. 2011.

[54] A. Ekholm and M. Molnar. "ICT development strategies for industrialisation of the building sector." Journal of Information Technology in Construction, 14(special issue), 429-444. 2009.

\section{AUTHORS}

Ehab J.Adwan is a Ph.D. candidate. He received his M.Sc. degree in Computer Science in 2004 from the University of Bahrain (UOB) and received his B.Sc. degree in Electronics and Physics with a minor in Computer in the year 1996 from The American University in Cairo (AUC). Since 1996, he is working as an Academic Research and Teaching Assistant (B) at the Department of information systems- College of Information Technology at the University of Bahrain. His mainstream research is focused on Enterprise Architecture,

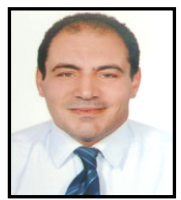
Business Architecture, Information Systems Architecture, Software Architecture, Software Engineering and Systems Analysis and Design,. Currently, great research emphasis is carried out on the ICT in Construction industry through an Enterprise Architecture perspective.

Dr. Ali AISoufi is an Associate professor of Information Systems at University of Bahrain. He has earned his $\mathrm{PhD}$ in Computer science in 1994 from Nottingham University, UK. He has worked for Bahrain Telecom Co for 8 years as a Senior Manager Application Programme where he overlooked number of mega IS Application projects. Worked at Arab Open University as the head of IT program and Assistant Director for Business Development during 2007-2010. He is a PT consultant in Bahrain e-Government Authority

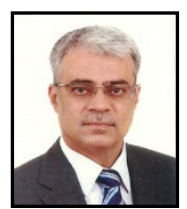
(EGA) in Enterprise Architecture. He is an active member of the Bahrain National ICT Governance Committee. His specializations is Strategic IT Planning and Governance, IT project management, Enterprise Architecture and IS in Organization 